\title{
A Business Success Versus Failure Prediction Model for Small Businesses in Israel
}

\author{
Shaike Marom \\ School of Management, Western Galilee College \\ PO Box 6567, Haifa 31064, Israel \\ E-mail: shaikem@wgalil.ac.il \\ Robert N. Lussier \\ Professor of Management, Department of Business Management \\ Springfield College, Springfield, MA 01109 \\ E-mail: rlussier@springfieldcollege.edu
}

Received: July 21, 2014 Accepted: August 5, 2014

doi:10.5296/ber.v4i2.5997ＵRL: http://dx.doi.org/10.5296/ber.v4i2.5997

\begin{abstract}
With the great discrepancy in the literature as to which variables do in fact lead to success or failure of small businesses there is no theory; the Lussier 15 variable business success versus failure prediction model stands out in its accuracy that has been tested and validated already in three very different parts of the world. This study further contributes by testing the model in Israel with a sample of 205 small businesses - 101 failed and 104 successful. Results support the model's validity in Israel, reinforcing its global validity and moving toward a theory; while demonstrating similarity of SMEs in Israel to those in other economies.
\end{abstract}

Keywords: Small businesses, Success factors, Entrepreneurship policy, Barriers to success

\section{Introduction}

Small and Medium-size Enterprises (SMEs) have been recognized by governments worldwide for their contribution to the economy stability and growth, employment and new job creation, and social cohesion and development (Morrison, Breen, \& Ali 2003; Organisation for Economic Co-operation and Development [OECD], 2004). Unfortunately, the failure rate of small businesses is high globally. Since entrepreneurship leads to economic growth, we need more successful entrepreneurs to grow economies and fewer failures wasting valuable 
resources. It is logical to conclude that if we can better understand why entrepreneurs fail, we should be able to increase the success to failure ratio. However, it has proven extremely difficult to predict which ventures will succeed and fail. It has recently become a hot topic because researchers have failed to understand, explain, and predict why some businesses succeed and others fail (Olaison \& Sorensen, 2014).

Moreover, during the economic recession of the last several years and the debt crisis in the euro zone, SMEs have retained their position as the backbone of the European economy accounting for more than 98 percent of all enterprises, for 67 per cent of total employment and 58 percent of gross value added (European Union [EU], 2012). In the U.S.A. small businesses make up 99.7 percent of U.S. employer firms, 49.2 percent of private-sector employment, 64 percent of net new private-sector jobs, and 33 percent of exporting value (Small Business Administration [SBA], 2012). Thus, creation and existence of SMEs is crucial for the stability of the economy, size and quality of employment, and socio-political structure of a nation (Nooteboom, 1988).

Given the importance of SMEs to economy and society (Nooteboom, 1988), public policy makers and other stakeholders have put efforts in helping to boosts creation of new small businesses and reduce the incidents of failure and bankruptcy (Carter \& Van Auken, 2006). Therefore, predicting SMEs fate in terms of success and failure has become an important area of research (Davidsson \& Klofsten, 2003; Lussier, 1995; Pompe \& Bilderbeek, 2005), as the lack of specific models is important because SMEs represent a significant part of the economy of virtually every nation (Ciampi \& Godini, 2013). Such research on the prediction of success versus failure would benefit current and would be entrepreneurs, as well as variety of other stakeholders including parties who assist and advise them, investors and institutions who provide them with capital, communities and society by and large (Dennis \& Fernald, 2001). However, finding out which factors lead to small business success and failure is still an ongoing and unfulfilled effort that research needs to continue to pursue (Rogoff, Lee, \& Sub, 2004).

Why do some businesses succeed and others end up bankrupt? There is great discrepancy in the literature as to which variables do in fact lead to success, thus, there currently is no theory (Lussier \& Halabi, 2010). Also, as stated by Bono and McNamar (2011), there is a need to test models in multiple countries to assess the robustness of the findings. To move the field in that direction, the goal of this research was to test the Lussier 15 variable success versus failure $[\mathrm{S} / \mathrm{F}]$ model in Israel, where there are no prior S/F research studies that could be found, which can further qualify its robustness for wide use as a global prediction model. Israel represents not only a different location on the globe, but also differs from others by size, age, economy, geo-political situation and highly diverse society and culture. Israel is in need of a S/F prediction model.

\section{Small Businesses in Israel}

\subsection{Israel Economy}

Although small, Israel is considered a highly developed country with a modern advanced market economy, as reflected in various ranking (Israel Ministry of Finance [MOF], 2012). 
According to the UN's Human Development Index [UNDP], as of 2012, Israel ranks 16th among 187 world nations, which places it in the top category of "Very Highly Developed" (UNDP, 2013). Israel's economy also ranks 19th among the world's most economically developed nations, according to International Institute for Management Development [IMD] World Competitiveness Yearbook (IMD, 2012); and rated 27th out of more than 130 countries in GDP per capita in PPP in 2011 standing at \$31,514, according to the International Monetary Fund (IMF, 2013). In addition to those rankings, Israel also became a member of the OECD in 2010 (Israel MOF, 2010), and has also signed free trade agreements with the European Union, the United States, and others.

The Israeli economy showed great resilience during the latest global economic crisis; and was ranked 1st in 2010-2011 by the 'Resilience of the Economy' Index, as part of the World Economic Forum Global Competitiveness Index (WEF, 2013). In addition, during the past two years, natural gas fields discovered off Israel's coast have strengthened Israel's energy security outlook, projecting energy independence by mid 2014 (Israel MOF, 2012).

Israel is a world class player in innovation, entrepreneurship and high tech industries. It is home to many international high tech companies, which identified its cultural and economic benefits, as well as its innovative spirit (Israel Ministry of Industry, Trade and Labor [MITL], 2010). This has earned Israel the attribute of a Start-up Nation, and 'The Israeli Silicon Valley'. Israeli companies, particularly in the high-tech area, have enjoyed considerable success raising money on Wall Street and other world financial markets, and as of 2010 the country was ranked second among foreign countries in the number of its companies listed on U.S. stock exchanges (Israel MITL, 2010; Israel MOF, 2012).

In absolute numbers, Israel is a relatively small country and economy (Israel Central Bureau of Statistics [CBS], 2011). Additionally, the country faces tough security challenges being isolated in the Middle East geo-political unstable situation, surrounded by numerous hostile countries.

\subsection{SMEs in Israel}

As of 2010 there were 478,000 active SMEs in Israel, constituting more than 99 percent of the total businesses in Israel, accounting for 55 percent of the workforce in the private sector, and for 45 percent of the country's' GNP, and about 15 percent of the export (Israel MITL, 2010). Thus, SMEs constitutes a major part of the country economy. Out of the total number of SMEs, about 75 percent employ up to four people, 14 percent employ 5 to 20 people, and the rest employ more than 20 people. Currently, the average annual net growth in number of SMEs is about 3 percent - with 10 percent of new SMEs and 7 percent closure (Small Business Authority of Israel [SBAI], 2011).

The definition of SMEs in Israel is based on Government resolution 2190 (Israel Government, 2007) as follows: Micro Business: Up to 5 employees and annual sales less than $\$ 2.8$ Million (Exchange rate \$U.S. 1 equals $3.5 \mathrm{New}$ Israel Shekel - NIS). Small Business: Up to 50 employees and annual sales less than \$ 7.1 Million. Medium Business: Up to 100 employees and annual sales less than $\$ 28$ Million. Despite this definition, they are not mandatory for all 
parties involved in SMEs. For example, the banking system has its own definitions of SMEs.

The main agency that deals and promotes SMEs in Israel is the Small Business Authority of Israel (SBAI, 2013). The SBAI was established in 1994 at the initiative of the Ministry of Industry and Trade, and is a non-profit association which operates as an independent entity in partnership with Government ministries, economic organizations and the public. The main objectives and functions of the SBAI are to promote and implement policies to encourage small and medium-sized businesses and to create tools for assisting them coordinate activities, provide professional support and guidance, and initiate the establishment of funds and other financial instruments to assist SMEs.

\subsection{Western and Israeli Differences}

Although the business environment of SMEs in Israel is similar in general to that in other western countries as reviewed above, there are some attributes of difference, including:

Geopolitical Situation: Located in the Middle East surrounded by countries that are mostly hostile, Israel SMEs can not grow by exporting over the borders to neighboring countries. According to the Uppsala Model of SMEs development (Johanson \& Vahlne, 1990; Johanson $\&$ Wiedersheim, 1975), growth may be accomplished first via cross neighboring border activity, which is not possible for SMEs in Israel, and thus their growth through internationalization must be directed overseas which presents a higher barrier to growth and survivability.

Population and Culture: Israel growth was based on waves of immigration of Jews from different parts of the world, which created a highly diverse society and culture (Israel CBS, 2011). Thus, the way owners manage and conduct their SME might follow many different patterns. Research has shown that owners' personal factors including perceptions and culture might have strong impact on the achievement of the business (Manolova et al., 2002).

High level of entrepreneurship: Israel is known for its unique entrepreneurial and innovative spirit, and leads the world in research and development endeavors, as reflected in the ratio of national expenditure on R\&D to the GDP, which stands at 4.4 percent (World Bank, 2011). It is also classified amongst the innovation-driven economies, together with the United States, United Kingdom, Germany, Sweden, and others. In the city of Tel Aviv, a city of 400,000, it has 700 tech startups eager to solve problems (Wainer, 2013). The central measure of GEM (Global Entrepreneurship Monitor) is the Total Entrepreneurial Activity (TEA) rate, which consists of the percentage of individuals aged $18-64$ years in an economy who are in the process of starting or are already running new businesses. The TEA rate therefore includes both nascent and new entrepreneurs. The TEA rating for Israel is 7, and it is lower than the other countries in which the Success vs. Failure Prediction Model has been tested: Croatia 8, USA 13, and Chile 23 (GEM, 2012).

According to previous research (Schwartz \& Malach-Pines, 2007), there are many differences between high technology entrepreneurs (HTE) and small business owners (SBOs), including HTEs' higher level of education, greater leadership experience and greater love of management. 


\section{Mll Macrothink}

Business and Economic Research

ISSN 2162-4860

2014, Vol. 4, No. 2

Thus, the high number of HTE type SMEs might have an impact on the success and failure dimensions.

\section{Conceptual Framework for Success versus Failure Model}

\subsection{Selection of the Model}

Prior success and failure model studies have been conducted by Carter and Van Auken (2006); Cooper, (1990); Cooper, Gascon, and Woo (1991); Dennis and Fernald (2001): Pompe and Bilderbeek (2005); Reynolds (1987); Reynolds and Miller (1989); van Gelder, de Vries, Frese, and Goutbeek (2007); Westhead et al. (2001). The Lussier (1995) model was selected to be used in this study for the following reasons. Lussier was the most extensive model because the study examined the efficacy of 15 variables identified from 20 prior studies. The Lussier (1995) model has been published in more journals (Lussier 1995, 1996a, 1996b; Lussier \& Corman, 1996; Lussier \& Pfeifer, 2000) and has been used to predict success and failure cross-nationally in the USA (Lussier, 1995), Croatia (Lussier \& Pfeifer, 2001), and in Chile (Lussier \& Halabi, 2010). The Lussier (1995) success versus failure ( $S / F)$ prediction model is also a nonfinancial model, which is more appropriate than financial models for small business research (Cooper, 1990; Cooper et al., 1991; Dennis \& Fernald. 2001; Reynolds, 1987; Reynolds \& Miller, 1989). In a more recent small business bankruptcy study, Van Auken et al. (2009) used a nonfinancial model. Also, most financial models use sales as a predictor, and are thus not appropriate to use with startup business (Scherr, 1989). Lussier also uses resource-based theory as entrepreneurs make judgments about which resources are more or less important based on their expectations about the future of the venture (Brush, 2001). There is also a current trend in research investigating the effects of human capital on growth and failure of newly founded businesses (Gedajlovic, Honig, Moore, Payne \& Wright, 2013; Rauch \& Rijsdijk, 2013), and the Lussier model also includes human capital variables - industry experience, management experience, and education. The Lussier model is designed to determine which variables are more and less important to success and failure. Thus, the Lussier (1995) model was selected for testing in Israel.

\subsection{Theoretical Background of the Model}

Lussier (1995) researched the literature to better understand why some businesses succeeded and others failed. To be included in the Lussier (1995) S/F model, a variable had to have been included in a study that had at least three variables identified as contributing factors to success and failure. Fifteen variables were identified in the literature and for each of the variables a hypotheses was developed to explain the relationship between the independent variable and the dependent variable performance - success vs. failure. See Table 1 for an explanation of the 15 independent success versus failure variables found in the Lussier model. Because a "model" was developed and tested, the 15 variable hypotheses are not tested and reported separately.

Table 1. Explanation of Success versus Failure Variables

Capital (capt). Businesses that start undercapitalized have a greater chance of failure than firms that start with adequate capital.

Record keeping and financial control (rkfc). Businesses that do not keep updated and accurate records 
and do not use adequate financial controls have a greater chance of failure than firms that do.

Industry Experience (inex). Businesses managed by people without prior industry experience have a greater chance of failure than firms managed by people with prior industry experience.

Management Experience (maex). Businesses managed by people without prior management experience have a greater chance of failure than firms that are managed by people with prior management experience.

Planning (plan). Businesses that do not develop specific business plans have a greater chance of failure than firms that do.

Professional Advisors (prad). Businesses that do not use professional advisors have a greater chance of failure than firms using professional advisors.

Education (educ). People without any college education who start a business have a greater chance of failing than people with one or more years of college education.

Staffing (staff). Businesses that cannot attract and retain quality employees have a greater chance of failure than firms that can.

Product/Service Timing (psti). Businesses that select products/services that are too new or too old have a greater chance of failure than firms that select products/services that are in the growth stage.

Economic Timing (ecti). Businesses that start during a recession have a greater chance to fail than firms that start during expansion periods.

Age (age). Younger people who start a business have a greater chance to fail than older people starting a business.

Partners (part). A business started by one person has a greater chance of failure than a firm started by more than one person.

Parents (pent). Business owners whose parents did not own a business have a greater chance of failure than owners whose parents did own a business.

Minority (mior). Minorities have a greater chance of failure than nonminorities.

Marketing (mrkt). Business owners without marketing skills have a greater chance of failure than owners with marketing skills.

There is little consistency in the literature supporting which variables do in fact explain and predict success vs. failure. Of the studies, the variable listed most frequently as a contributing factor to success vs. failure was the need for planning. However, planning was only cited in 16 (55\%) of the studies. See Table 2 for a comparison of variables identified in 30 articles in the literature as factors contributing to success versus failure; note that the Lussier (1995) list included 20 studies and the resulting discrepancies haven't decreased in close to 20 years. Due to such a large discrepancy in the literature, there is no strong unifying theory of success vs. failure. Thus, this study is an attempt to help clarify which variables do in fact explain and predict success vs. failure as we move towards a unifying theory.

An extensive literature review was conducted to identify these entrepreneurial behavior variables that have been found to support the success of small businesses, including planning behavior and the use of formal written business plan (Mazzarol et al., 2009), seeking professional advise including financial issues (Dobbs \& Hamilton, 2007), previous knowledge and education (Chowdhury et al., 2013; Gabrielsson \& Politis, 2012; Pickernell et al., 2011), previous experience in the industry (Chowdhury et al., 2013; Gabrielsson \& Politis, 2012; Ulvenblad et al., 2013), and owner concentrating on the marketing domain (Simpson et al., 
2006).

Table 2. A Comparison of Variables Identified in 30 Articles as Factors Contributing to Business Success versus Failure

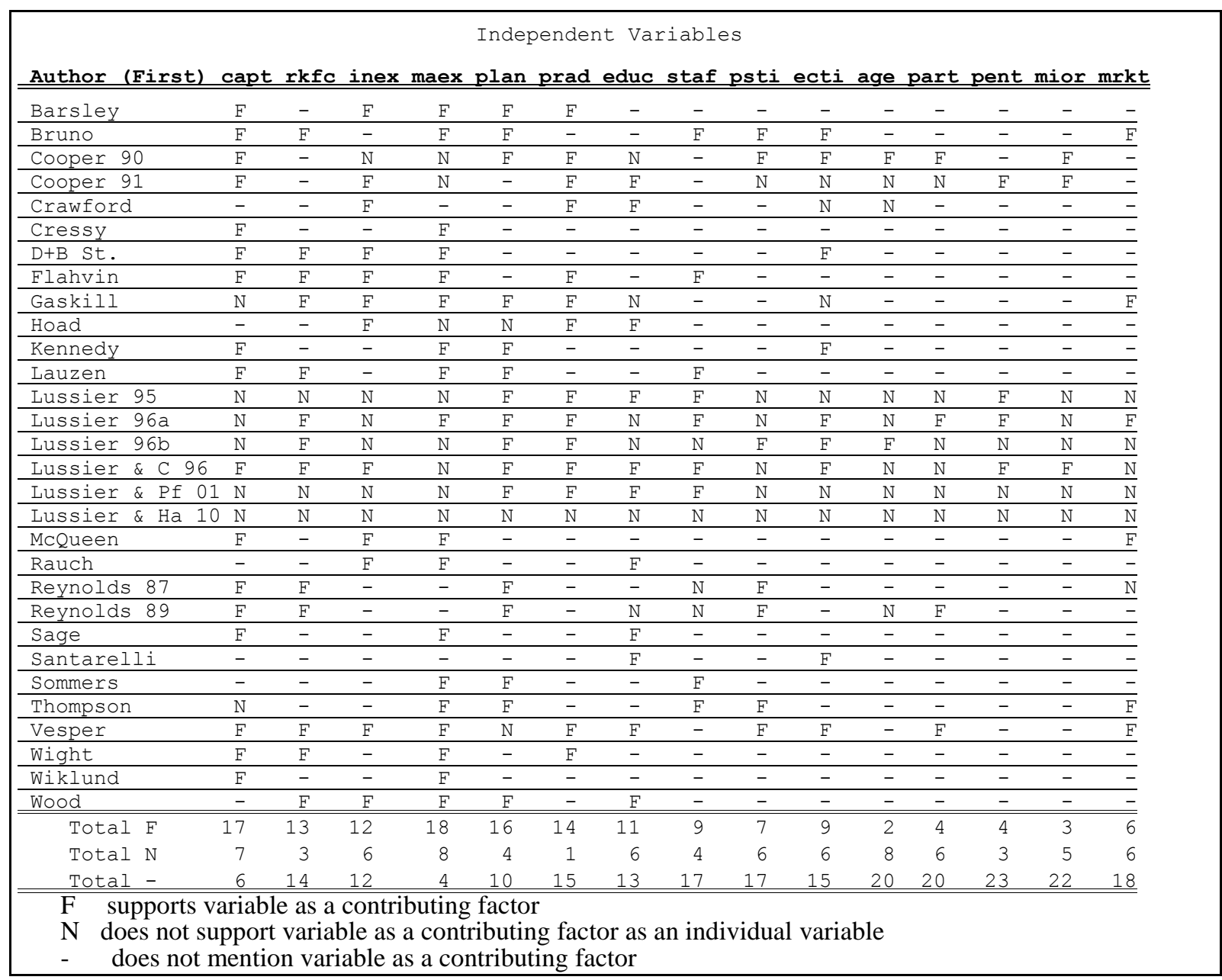

The model includes all 15 variables identified in the literature review. Although, prior researchers concluded that success factors vary in different countries (Benzing et al., 2009), the $\mathrm{S} / \mathrm{F}$ model was significant in three very different countries and parts of the world. Thus, the primary research hypothesis was that the model would also predict S/F in Israel.

\section{Method}

The primary methodology of this study was survey research using the previously validated Lussier (1995) research study questionnaire in Israel. The questionnaire was translated to Hebrew to adapt to the local language by a professional and the questionnaire was pilot tested for accuracy in translation.

A total of 340 businesses were contacted through random selection within six industrial parks and commerce centers in the northern region of Israel, as well as from bankruptcy records of the Ministry of Justice. The questionnaires were administered by post and e-mail, within a period of three months. There were 242 completed surveys, resulting in a response rate of 71 percent. However, 37 had missing data, resulting in 205 usable questionnaires. Thus, 205 


\section{Ml Macrothink}

Business and Economic Research ISSN 2162-4860 2014, Vol. 4, No. 2

questionnaires were included with 104 (51\%) classified as successful, and 101 (49\%) classified as failures were included for statistical analysis. Businesses that were operational at the time of study where termed successful, while bankrupt businesses and businesses that cease operations where termed failures.

This study has a large sample sizes (205) and response rate (71\%) considering Carter and Van Auken (2006) used a sample of 57 bankrupt and 55 non-bankrupt firms with a response rate of 16 percent, and van Gelder et al. (2007) used 71 operational and only 20 failed business owners. The Lussier (1995) U.S.A. study was based on 216 businesses (108 successful and failed) with a response rate of 39 percent.

\section{Results and Discussion}

Table 3 contains the means and standard deviations among the 15 independent variables in the regression equation for the 205 Israeli businesses, and test of differences between the successful and failed firms. The results of the logistic regression analysis appear in Table 4.

Table 3. Israel Descriptive Statistics and Test of Differences $(\mathrm{N}=205)$

\begin{tabular}{|c|c|c|c|c|c|}
\hline $\begin{array}{c}\text { Model } \\
\text { Variables }\end{array}$ & Coded & $\begin{array}{c}\text { Failed } \\
\text { Mean/ } \\
{[\text { Frequency] }} \\
(\mathbf{n}=\mathbf{1 0 1})\end{array}$ & $\begin{array}{c}\text { Failed } \\
\text { s.d. }\end{array}$ & $\begin{array}{c}\text { Success } \\
\text { Mean/ } \\
{[\text { Frequency }]} \\
(\mathbf{n}=\mathbf{1 0 4}) \\
\end{array}$ & $\begin{array}{c}\text { Success } \\
\text { s.d. }\end{array}$ \\
\hline 1. Capital & 1 adequate -7 inadequate $^{1}$ & 4.15 & 1.314 & 3.04 & $1.033 * *$ \\
\hline $\begin{array}{l}\text { 2. Record keeping \& } \\
\text { financial control }\end{array}$ & 1 poor - 7 good & 3.52 & 1.230 & 4.86 & $0.960 * *$ \\
\hline 3. Industry experience & \# of years & 3.46 & 2.189 & 3.63 & 1.947 \\
\hline $\begin{array}{l}\text { 4. Management } \\
\text { experience }\end{array}$ & \# of years & 3.53 & 2.115 & 2.48 & $1.768 * *$ \\
\hline 5. Planning & 1 specific - 7 no plan ${ }^{1}$ & 3.53 & 1.277 & 2.18 & $0.760 * *$ \\
\hline 6. Professional advice & 1 used -7 not used $^{1}$ & 3.95 & 1.260 & 2.97 & $1.234 * *$ \\
\hline 7. Education & $0 \mathrm{GS}-4 \mathrm{PhD}$ & 1.39 & 0.860 & 1.57 & 0.822 \\
\hline 8. Staffing & 1 easy - 7 difficult ${ }^{1}$ & 4.62 & 1.256 & 5.04 & $0.985^{* *}$ \\
\hline $\begin{array}{l}\text { 9. Product/service } \\
\text { timing }\end{array}$ & 1 intro. -7 decline ${ }^{1}$ & 4.18 & 1.299 & 4.43 & 0.963 \\
\hline 10. Economic timing & 1 recession -7 expand & 4.05 & 0.792 & 4.50 & $0.711 * *$ \\
\hline 11. Age of Owner & number of years & 34.21 & 5.443 & 31.50 & $3.631 * *$ \\
\hline 12. Partners & $\#$ with partners / \% & {$[30 / 30 \%]$} & & {$[29 / 28 \%]$} & \\
\hline 13. Parents & $\begin{array}{l}\text { \# parents owned a business } \\
1 \%\end{array}$ & {$[36 / 36 \%]$} & & {$[39 / 38 \%]$} & \\
\hline 14. Minority & 1 yes -2 no & {$[24 / 24 \%]$} & & {$[20 / 19 \%]$} & \\
\hline 15. Marketing & 1 unskilled - 7 skilled & 3.75 & 1.236 & 3.90 & 1.390 \\
\hline
\end{tabular}

${ }^{1}$ Note that these are reverse scale items. Thus, a lower number is preferred or expected.

* Success and failure mean difference is significant at the .05 level. 
** Success and failure mean difference is significant at the .01 level.

\subsection{Test of Differences}

As shown in Table 3, the successful firms had higher levels of six of the variables. Thus, if small businesses have adequate capital, maintain good record keeping and financial control, have management experience, have specific plans, make use of professional advice, and have good economic timing, they will increase their chances of success.

Table 4. Logistic Regression Model Test Results Israel

\begin{tabular}{|l|c|c|}
\hline \multirow{2}{*}{ Model Parameter Estimates } & \multicolumn{2}{|c|}{ Model } \\
\cline { 2 - 3 } Variables Name & $\boldsymbol{\beta}$ & Sig. \\
\hline 1. Capital & .568 & $\mathbf{. 0 0 4}$ \\
\hline 2. Record keeping and financial control & -.791 & $\mathbf{. 0 0 1}$ \\
\hline 3. Industry experience & -.189 & .101 \\
\hline 4. Management experience & .072 & .579 \\
\hline 5. Planning & .969 & $\mathbf{. 0 0 0}$ \\
\hline 6. Professional advice & .500 & $\mathbf{. 0 1 3}$ \\
\hline 7. Education & .535 & .081 \\
\hline 8. Staffing & -.148 & .492 \\
\hline 9. Product/service timing & -.077 & .716 \\
\hline 10. Economic timing & -.565 & .090 \\
\hline 11. Age of owner & .135 & $\mathbf{. 0 2 1}$ \\
\hline 12. Partners & .796 & .112 \\
\hline 13. Parents owned a business & .685 & .155 \\
\hline 14. Minority & .162 & .774 \\
\hline 15. Marketing & .315 & .108 \\
\hline Constant & -8.055 & .017 \\
\hline & & \\
\hline Model Test Results & & \\
\hline -2 Log Likelihood & 145.081 & \\
\hline Model Chi-square & 139.065 & \\
\hline Model Significance & $\mathbf{. 0 0 0}$ & \\
\hline R Square & $\mathbf{. 6 5 7}$ & \\
\hline & & \\
\hline Classification Results & & \\
\hline Correctly Classified Cases & & \\
Success & $84.6 \%$ & \\
Oailed & $86.1 \%$ & \\
\hline
\end{tabular}

\subsection{Test of the Model}

The $-2 \log$ likelihood (LL) for the model is 145.081. The large -2 LL statistic indicates that the model does not differ significantly from the "perfect" model. The logistic regression results testing the model Chi-square was 139.065 with the model significance level less than .01 (p $=.000)$. Thus, the model has empirical validity as $99 \%$ of the time it will be more accurate than random guessing of which businesses are successful and failed. Results support the model's ability to predict success and failure in Israel. Thus, if the small businesses have adequate capital, maintain good record keeping and financial control, have prior industry and management experience, have specific plans, make use of professional advice, have higher 
levels of education, do a good job of staffing, have good product/service and economic timing, have partners, parents that owned a business, and have marketing skills, they will increase their chances of success. Age has also been found significant, but has little importance, as is discussed below.

The ability of the model to predict a specific business as successful or failed accurately overall was 85.4 percent of the businesses. The model had similar prediction level of business failure (86\%) and success (84\%). The predictive results are more accurate than the Lussier (1995) U.S.A. study (70\%), and the Lussier and Pfeifer (2001) Croatian study accuracy (72\%), and Lussier and Halabi (2010) Chile study accuracy (63\%). The fact that results are similar to those found in the U.S.A. supports previous findings that success predictors for small businesses would be similar in traditional market economies (Kessler, 2007).

Many published regression model studies using large sample sizes are supported with significant p-values, but are not supported by having low adjusted R-square values. The validity of the Lussier (1995) model in Israel is also supported by the high Nagelkerke $\mathrm{R}$-square value (.657), indicating that only 33 percent of the variance in success versus failure is explained by other variable not in the model.

Thus, based on the model, small business owners in the U.S.A. and Israel need to focus on the variables in order to improve their chances of success and decrease their chances of failure. With the current global economy downturn, the economic timing variable becomes important. New startups should be sure that they have specific plans that include having adequate capital, good record keeping and financial control, and a marketing sales forecast to ensure sales and cash flow to keep the firm solvent; and the business plan will be improved through the use of professional advice.

\subsection{Previous Research}

The model test results $(\mathrm{p}=.000)$ do support Lussier $(1995)$ because the model did predict success and failure in the U.S.A. $(p=.001)$ and Chile $(p=.004)$. However, the model was not significant in the Lussier and Pfeifer (2001) Croatian study. The contrary results may be due to a different smaller sample size in Croatia $(\mathrm{N}=120)$ versus the U.S.A. $(\mathrm{N}=216)$, Chile $(\mathrm{N}=$ 234), and Israel $(\mathrm{N}=205)$. In Croatia there were only 36 failed firms, with 84 successful firms. Thus, the model has predictive validity because it is significant in the Middle East Israel, South American Chile, and North America U.S.A., or the model fits the data. In other words, the model will reliably predict a group of businesses as failed or successful more accurately than random guessing in all three countries over 99 percent of the time.

It is difficult to compare results of this study using the Lussier (1995) model to prior studies not using the same model; because of the wide discrepancy among prior research identifying which variables do in fact predict success or failure (Lussier \& Halabi 2010). Also, only four other studies actually developed a nonfinancial model to predict success vs. failure using logistic regression (Cooper et al., 1990, 1991; Reynolds. 1987, Reynolds \& Miller, 1989). Other studies tried to determine factors of success vs. failure without models and logistical regression. For example, Gaskill, Van Auken and Manning (1993) conducted a factor analytic study of the 
perceived causes of small business failure. Reynolds (1987) and Reynolds and Miller (1989) used age of the business and first year sales as predictors of success or failure, which are unknown variables in predicting success or failure of a new venture. The Cooper et al. (1990, 1991) did not actually survey failed businesses.

\subsection{Individual Variables in the Model, Near Multicollinearity, and Test of Differences}

The parameter estimated beta coefficients appear in Table 4. Of the 15 variables in the model, the parameter estimates for the logistic regression model found five of the variables to be significant. This indicates that businesses started with adequate capital $(p=.004)$, have good record keeping and financial controls $(\mathrm{p}=.001)$, develop plans $(\mathrm{p}=.000)$, and use professional advisors $(\mathrm{p}=.013)$, have a significantly greater chance of success from failure in Israel. Age was also significant $(\mathrm{p}=.021)$ and the result contradicted the literature suggesting that starting a business at an older age improves the chances of success. However, it is not important as the mean ages were failed entrepreneurs was 34.21 and success 31.50 , for a difference of 2.71 years. Finding this small difference in age to be significant is most likely due to having a large sample size $(\mathrm{N}=205)$. It is not logical to suggest staring a business a couple of years earlier, as the key criteria should be to start when the entrepreneur finds a good opportunity.

The most likely reason for the lack of significance for the other individual independent variables is because the model has near multicollinearity. Near multicollinearity, also called faced or just multicollinearity, exist when one independent variable is linearly dependent to one or more other independent variables; without the variable(s) the estimators would not exist. For example, the number of years of industry experience, the number of years of management experience, and the age of the owner are exceedingly likely to be correlated.

Returning to Table 3, the results of 10 out of the 15 test of differences between the successful and failed resources, supports the Lussier (1995) model. The following variables were significantly different. Successful firms (1) started with greater capital ( $p=.000)$, had better (2) record keeping and financial control $(\mathrm{p}=.000),(4)$ more years of management experience $(\mathrm{p}$ $=.000),(5)$ more specific plans $(\mathrm{p}=.000),(6)$ made greater use of outside professional advisors $(\mathrm{p}=.000),(8)$ had an easier time staffing $(\mathrm{p}=.009),(10)$ better economic timing $(\mathrm{p}$ $=.000)$, but $(11)$ the owner was younger $(\mathrm{p}=.000)$. Thus, these variables may be more important than the others in distinguishing success from failed businesses in Israel.

\subsection{Multicolinlinearity}

Correlation analysis was run to assess the degree of multicollinearity among the 15 variables. The correlation matrix (Table 5) shows that most of the correlations are relatively low. While some of the correlations are significant, of the 105 correlations only 2 are greater than .50 and 25 are greater than .20. The correlations also have lower covariance than the Lussier (1995) study. Thus, the covariance is low and multicollinearity should not be problematic in the model (Lussier, 2011).

Table 5. Correlation Between Variables 


\begin{tabular}{|c|c|c|c|c|c|c|c|c|c|c|c|c|c|c|}
\hline & 1 & 2 & 3 & 4 & 5 & 6 & 7 & 8 & 9 & 10 & 11 & 12 & 13 & 14 \\
\hline \multicolumn{15}{|l|}{ 1. Capital } \\
\hline 2. Record Keep. \& Fin. Con. & $-.393^{\star *}$ & & & & & & & & & & & & & \\
\hline 3. Industry Experience & -0.027 & 0.044 & & & & & & & & & & & & \\
\hline 4. Management Experience & 0.075 & $-.154^{*}$ & $.169^{* *}$ & & & & & & & & & & & \\
\hline 5. Planning & $336^{* *}$ & $-.490^{* *}$ & -0.058 & $.186^{\star *}$ & & & & & & & & & & \\
\hline 6. Professional Advice & $.320^{* \star}$ & $-.378^{\star \star}$ & -0.006 & $.128^{*}$ & $.268^{* *}$ & & & & & & & & & \\
\hline 7. Education & $-.194^{\star *}$ & $.278^{\star *}$ & $.121^{*}$ & -0.081 & $-.150^{*}$ & $-.228^{* *}$ & & & & & & & & \\
\hline 8. Staffing & $-.132^{*}$ & $.270^{\star *}$ & 0.020 & -0.041 & $-.149^{*}$ & -0.085 & -0.044 & & & & & & & \\
\hline 9. Product/Service Timing & -0.029 & 0.058 & 0.016 & -0.002 & -0.081 & -0.008 & $-.153^{*}$ & $.174^{* *}$ & & & & & & \\
\hline 10. Economic Timing & -0.112 & $.261^{* *}$ & $.116^{*}$ & $-.131^{*}$ & $-.223^{\star \star}$ & $-.252^{\star \star}$ & 0.050 & 0.024 & $.123^{\star}$ & & & & & \\
\hline 11. Age of Owner & 0.049 & -0.099 & $.317^{\star \star}$ & $.482^{\star *}$ & $.228^{\star *}$ & 0.106 & -0.068 & 0.062 & 0.114 & -0.104 & & & & \\
\hline 12. Parthers & -0.104 & 0.069 & 0.094 & 0.070 & -0.087 & $-.192^{\star *}$ & 0.049 & -0.021 & $-.133^{\star}$ & 0.022 & 0.031 & & & \\
\hline 13. Parents Owned a Bus. & -0.055 & 0.071 & -0.046 & 0.015 & -0.052 & 0.053 & -0.098 & 0.023 & 0.000 & 0.076 & 0.044 & -0.032 & & \\
\hline 14. Minority & -0.057 & $.146^{*}$ & 0.016 & 0.077 & $-.159^{*}$ & $-.134^{*}$ & 0.043 & -0.066 & -0.088 & -0.012 & -0.070 & $.175^{\star \star}$ & 0.096 & \\
\hline 15. Marketing & $-.136^{\star}$ & $.241^{\star \star}$ & $.224^{\star \star}$ & $.231^{\star \star}$ & -0.100 & $-.276^{* \star}$ & $.237^{\star \star}$ & 0.066 & -0.111 & $213^{\star \star}$ & 0.110 & $.214^{\star \star}$ & -0.060 & 0.104 \\
\hline
\end{tabular}

\section{Use of the Model, Limitations and Further Research}

The model does not provide numerical guidelines for variables distinguishing success from failure. Judgment is needed when applying the model. The user must look at the list of variables in the model and subjectively assess the strengths of the business for each variable. A system of assigning a rating of strong, moderate, or weak to each variable can be used. Then an overall rating of strong, moderate or weak can be assigned to the probability of success. When the business is strong on some variables and weak on others, the judgmental assignment of a probability of success is more subjective. With mixed strengths and weaknesses among the variables, the other decision criteria previously used by entrepreneurs, managers, investors, lenders, and suppliers become increasingly important when they assign a probability of success or failure to a business.

Although this study has used rigorous methodology and an extensive model with 15 variables to explore success versus failure, we acknowledge that it has certain limitations. First, this research was based on data that has been collected at a single point in time; rather than a longitudinal study. This could mean that if the same research would be conducted at different times; such as during recession or prosperous years, results might be different. For example, the variable of economic timing of starting a business may be more critical during recession. A second limitation arises out of the fact that the model includes subjective measures. The fact is that about half of the 15 variables are based on self-reporting data. Thus, the model should be used as a technique to improve decision making, but not as a sole predictor for success versus failure of a business.

Additional limitations of this study arise out of its global distribution. First, with the current study in Israel, the Lussier (1995) prediction model has been tested in only four countries globally. With somewhat different results in the four countries, there is a need to further validate the model in other countries to compare results. In doing so, a global success versus failure prediction model and theory may develop. Second, there is a cross-cultural study limitation because of the many differences between the countries where the model has been tested. Those differences include legal systems, economies, attitudes towards business, and other factors.

Future research should seek to improve on the limitations of the study. Researchers may make 
data collection less subjective by measuring more objectively some of the existing subjective variables, and use other methods of obtaining data. Future research can take a longitudinal methodology rather than cross-sectional. Additionally, future researchers may test the model in other countries, as well as develop cultural control variables and explore how regulatory environments, economics and culture affect business success and failure.

\section{Implications and Conclusions}

Public policy makers in Israel do realize the importance of the small business sector because of its major contribution to the economy as well as its significant share to the local employment market. It is the reason that resources are allocated each year for support programs to SMEs. However, a question remains about the effective use of those resources, following reports that the failure percentage of small businesses in Israel is amongst the highest within the OECD (OECD, 2012). The Small Business Authority of Israel (SBAI) that is tasked with providing guidance and support to small businesses, similar to the SBA in the U.S.A.; could increase effectiveness by considering the critical variables as found in this research.

The study success factors can contribute to the local economy in several ways. First, this knowledge is applicable to the high-tech start-up sector, which has proven highly important for the economy of Israel. With 772 Israeli start-ups during the last decade (Calcalist, 2013), contributing $\$ 41.6$ billion to the country's economy, it is highly important to direct support program resources effectively, strengthening the major success variables. Second, it could serve policymakers to identify these successful start-up firms that are highly likely to attract major investments in the local economy. For example, big leading companies like Google, Apple, Microsoft and Facebook, have invested in successful start-up firms in Israel. Moreover, those companies have set up local development centers, which further boost innovation that serves future growth, as well as creating new jobs. Thirdly, the current low unemployment rate in Israel is due to the small business sector, which creates new jobs (SBAI, 2011).

Thus, it would be highly useful to use the findings of this research to identify these small firms that are more likely to succeed, further supporting a high level of local employment. Therefore, such support programs should consider offering more low interest loans so that entrepreneurs don't continue to start undercapitalized, as well as provide an understanding of the capital needs to start a business and how to keep records and financial controls. Additionally, more professional advice can be provided regarding how to develop a business plan, management and marketing training, and how to keep records and financial controls. The success factors found in this research and the derived recommendations are applicable to all the segments of the small businesses in Israel, and thus, there is a need to direct support program resources effectively, strengthening the major success variables..

The fact that the Lussier (1995) model variables do in fact predict success and failure in four very different parts of the world, North America U.S.A., South America Chile, Central Eastern Europe Croatia, and in the Middle East Israel, is of importance because success versus failure prediction research benefits both the would be and current entrepreneurs; those who assist, train and advise them; those who provide capital for their ventures; their suppliers; and public policy makers. If they use the model to assess a firm's potential for success, society can benefit 
in direct and indirect ways via the allocation of limited resources (entrepreneurial capital, investments and loans, government aid, and so forth) toward higher potential businesses.

A promising finding of this study is that although there is great discrepancy in the literature, see Table 2, and great differences between countries, the Lussier (1995) model is significant in four different countries from varying parts of the world. Maybe business success vs. failure variables in different countries are more similar than people realize, or maybe it is the effect of globalization. The exploratory global success vs. failure prediction model may be a significant predictor in other countries as well. Although there is much discrepancy in the literature, and no unifying theory, this study helps to move us in that direction. With the trend toward increasing globalization, international global business success vs. failure prediction models become more valuable.

\section{References}

Benzing, C., Chu, H. M., \& Kara, O. (2009). Entrepreneurs in Turkey: A factor analysis of motivations, success factors, and problems. Journal of Small Business Management, 47(1), 58-91. http://dx.doi.org/10.1111/j.1540-627X.2008.00262.x

Bono, J. E., \& McNamara, G. (2011). Publishing in AMJ-Part 2: Research design. Academy of Management Journal, 54(4), 657-660. http://dx.doi.org/10.5465/AMJ.2011.64869103

Brush, C. (2001). How do "resource bundles" develop and change in new ventures? A dynamic model and longitudinal exploration. Entrepreneurship theory and practice, 25(3), 37-58.

Calcalist (2013). Ten years, 772 Exits, and \$ 41.6 Billion. Calcalist newspaper article March, 23, 2013. [Online] Available: http://www.calcalist.co.il/internet/articles/0,7340,L -3598587,00.html (May 15, 2014).

Carter, R., \& Auken, H. V. (2006). Small firm bankruptcy. Journal of Small Business Management, 44(4), 493-512. http://dx.doi.org/10.1111/j.1540-627X.2006.00187.x

Ciampi, F., \& Gordini, N. (2013). Small enterprise default prediction modeling through artificial neural networks: An empirical analysis of Italian small enterprises. Journal of Small Business Management, 51(1), 23-45. http://dx.doi.org/10.1111/j.1540-627X.2012.00376.x

Chowdhury, M. S., Alam, Z., \& Arif, M. I. (2013). Success Factors of Entrepreneurs of Small and Medium Sized Enterprises: Evidence from Bangladesh. Business and Economic Research, 3(2), 38-52. http://dx.doi.org/10.5296/ber.v3i2.4127

Cooper, A. C. (1990). New Business in America. The Firms and Their Owners. The National Federation of Independent Business Foundation, 600 Maryland Avenue, SW, Suite 700, Washington, DC 20024.

Cooper, A. C., Gimeno-Gascon, F. J., \& Woo, C. Y. (1991, August). A Resource-based prediction of new venture survival and growth. In Academy of Management Proceedings (Vol. 1991, No. 1, pp. 68-72). Academy of Management.

Davidsson, P., \& Klofsten, M. (2003). The business platform: Developing an instrument to 
gauge and to assist the development of young firms. Journal of Small Business Management, 41(1), 1-26. http://dx.doi.org/10.1111/1540-627X.00064

Dennis, W. J., \& Fernald, L. W. (2001). The chances of financial success (and loss) from small business ownership. Entrepreneurship Theory and Practice, 26(1), 75-83.

Dobbs, M., \& Hamilton, R. T. (2007). Small business growth: recent evidence and new directions. International Journal of Entrepreneurial Behaviour \& Research, 13(5), 296-322. http://dx.doi.org/10.1108/13552550710780885

EU (2012). EU SMEs in 2012: at the crossroads. Annual report on small and medium-sized enterprises in the EU, 2011/12.

Gabrielsson, J., \& Politis, D. (2012). Work experience and the generation of new business ideas among entrepreneurs: An integrated learning framework. International Journal of Entrepreneurial Behaviour \& Research, 18(1), 48-74. http://dx.doi.org/10.1108/13552551211201376

Gaskill, L. R., Van Auken, H. E., \& Manning, R. A. (1993). A factor analytic study of the perceived causes of small business failure. Journal of Small Business Management, 31, 18-18.

Gedajlovic, E., Honig, B., Moore, C. B., Payne, G. T., \& Wright, M. (2013). Social capital and entrepreneurship: A schema and research agenda. Entrepreneurship Theory and Practice, 37(3), 455-478. http://dx.doi.org/10.1111/etap.12042

GEM (2012). Global Entrepreneurship Monitor - 2012 Global Report. [Online] Available: http://www.gemconsortium.org/docs/download/2645 (May 15, 2014).

International Institute for Management Development - IMD (2012). World Competitiveness Rankings 2012. [Online] Available: http://www.imd.org/research/publications/ wcy/upload/scoreboard.pdf (May 15, 2014).

International Monetary Fund - IMF (2013). World Economic Outlook Database. [Online] Available: http://www.imf.org/external/pubs/ft/weo/2013/01/weodata/index.aspx (May 15, 2014).

Israel Central Bureau of Statistics - CBS (2011). Israel in Figures 2011. [Online] Available: http://cbs.gov.il/www/publications/isr_in_n11e.pdf (May 15, 2014).

Israel Government (2007). Israel Government Decision 2190, dated August 12, 2007: Supporting SMEs. [Online] Available: http://147.237.77.193/Secretary/GovDecisions/2007/ Pages/des2190.aspx (May 15, 2014).

Israel Ministry of Industry, Trade and Labor - MITL (2010). ISRAEL: Global Center for Breakthrough Innovation. Ministry of Industry, Trade and Labor, Investment Promotion Center. [Online] Available: http://www.moital.gov.il/NR/rdonlyres/D20FF2AA-23AA-4D5F -8D44-8CD1DD61127B/0/Innovationbrochure2010.pdf. (May 15, 2014).

Israel Ministry Of Finance - MOF (2010). Israel Joins the OECD. Press Release 0202-328, dated May 10, 2010; Israel Ministry of Finance (MOF), International Affairs Department. 
[Online] Available: http://www.financeisrael.mof.gov.il/FinanceIsrael/Docs/En/press Releases/20100510.pdf (May 15, 2014).

Israel Ministry of Finance - MOF (2012). The Israeli Economy: Fundamentals, Characteristics and Historic Overview. Israel Ministry of Finance (MOF), International Affairs Department, Fall 2012. [Online] Available: http://www.finance israel.mof.gov.il/FinanceIsrael/Docs/En/The_Israeli_Economy_2012.pdf (May 15, 2014).

Johanson, J., \& Vahlne, J. E. (1990). The mechanism of internationalisation. International marketing review, 7(4), 11-24. http://dx.doi.org/10.1108/02651339010137414

Johanson, J., \& Wiedersheim - Paul, F. (1975). The internationalization of the firm-four swedish cases 1. Journal of management studies, 12(3), 305-323. http://dx.doi.org/10.1111/j.1467-6486.1975.tb00514.x

Kessler, A. (2007). Success factors for new businesses in Austria and the Czech Republic. Entrepreneurship and regional development, 19(5), 381-403. http://dx.doi.org/10.1080/08985620701439959

Lussier, R. N. (1995). A nonfinancial business success versus failure prediction model for young firms. Journal of Small Business Management, 33(1), 8-20.

Lussier, R. N. (1996a). A business success versus failure prediction model for service industries. Journal of Business and Entrepreneurship, 8(2), 23-37.

Lussier, R. N. (1996b). A startup business success versus failure prediction model for the retail industry. Mid-Atlantic Journal of Business, 32(2), 79-92.

Lussier, R. N. (2011). Research methods and statistics for business. Waveland.

Lussier, R. N., \& Corman, J. (1996). A business success versus failure prediction model for entrepreneurs with 0-10 employees. Journal of Small Business Strategy, 7(1), 21-35.

Lussier, R. N., \& Halabi, C. E. (2010). A Three - Country Comparison of the Business Success versus Failure Prediction Model. Journal of Small Business Management, 48(3), 360-377. http://dx.doi.org/10.1111/j.1540-627X.2010.00298.x

Lussier, R. N., \& Pfeifer, S. (2000). A Comparison of Business Success Versus Failure Variables Between US and Central Eastern Europe Croatian Entrepreneurs. Entrepreneurship Theory and Practice, 24(4), 59-67.

Lussier, R. N., \& Pfeifer, S. (2001). A crossnational prediction model for business success. Journal of Small Business Management, 39(3), 228-239. http://dx.doi.org/10.1111/0447-2778.00021

Manolova, T. S., Brush, C. G., Edelman, L. F., \& Greene, P. G. (2002). Internationalization of Small Firms Personal Factors Revisited. International Small Business Journal, 20(1), 9-31. http://dx.doi.org/10.1177/0266242602201003

Mazzarol, T., Reboud, S., \& Soutar, G. N. (2009). Strategic planning in growth oriented small 
firms. International Journal of Entrepreneurial Behaviour \& Research, 15(4), 320-345. http://dx.doi.org/10.1108/13552550910967912

Nooteboom, B. (1988). The Facts About Small Business and the Real Values of Its 'Life World': A Social Philosophical Interpretation of This Sector of the Modem Economy. American journal of economics and sociology, 47(3), 299-314. http://dx.doi.org/10.1111/j.1536-7150.1988.tb02043.x

Morrison, A., Breen, J., \& Ali, S. (2003). Small business growth: intention, ability, and opportunity. Journal of small business management, 41(4), 417-425.

OECD (2004). Promoting entrepreneurship and innovative SMEs in a global economy. The 2nd OECD Conference on Small and Medium-Sized Enterprises (SMEs), Istanbul, Turkey, 3-5 June 2004.

OECD (2012), Entrepreneurship at a Glance 2012. [Online] Available: http://dx.doi.org /10.1787/entrepreneur_aag-2012-en (May 15, 2014).

Olaison, L., \& Sørensen, B. M. (2014). The abject of entrepreneurship: failure, fiasco, fraud. International Journal of Entrepreneurial Behaviour \& Research, 20(2), 193-211. http://dx.doi.org/10.1108/IJEBR-09-2013-0143

Pickernell, D., Packham, G., Jones, P., Miller, C., \& Thomas, B. (2011). Graduate entrepreneurs are different: they access more resources?. International Journal of Entrepreneurial Behaviour \& Research, 17(2), 183-202. http://dx.doi.org/10.1108/13552551111114932

Pompe, P. P., \& Bilderbeek, J. (2005). The prediction of bankruptcy of small-and medium-sized industrial firms. Journal of Business Venturing, 20(6), 847-868. http://dx.doi.org/10.1016/j.jbusvent.2004.07.003

Rauch, A., \& Rijsdijk, S. A. (2013). The Effects of General and Specific Human Capital on Long - Term Growth and Failure of Newly Founded Businesses. Entrepreneurship Theory and Practice, 37(4), 923-941. http://dx.doi.org/10.1111/j.1540-6520.2011.00487.x

Reynolds, P. D. (1987). New firms: societal contribution versus survival potential. Journal of Business Venturing, 2(3), 231-246.

Reynolds, P. D., \& Miller, B. (1989). New firm survival: analysis of a panel's fourth year. Strategic Management Research Center, University of Minnesota. http://dx.doi.org/10.1016/0883-9026(87)90011-5

Rogoff, E. G., Lee, M. S., \& Suh, D. C. (2004). “Who done it?” Attributions by entrepreneurs and experts of the factors that cause and impede small business success. Journal of Small Business Management, 42(4), 364-376. http://dx.doi.org/10.1111/j.1540-627X.2004.00117.x

Scherr, F. C. (1989). Causality, regression, discriminant analysis, and research on failure. Akron Business and Economic Review, 20(1), 8-20.

Schwartz, D., \& Malach-Pines, A. (2007). High technology entrepreneurs versus small business owners in Israel. Journal of entrepreneurship, 16(1), 1-17. 
http://dx.doi.org/10.1177/097135570601600101

Simpson, M., Padmore, J., Taylor, N., \& Frecknall-Hughes, J. (2006). Marketing in small and medium sized enterprises. International Journal of Entrepreneurial Behaviour \& Research, 12(6), 361-387. http://dx.doi.org/10.1108/13552550610710153

Small Business Authority - SBA (2012). Frequently Asked Questions about Small Business. SBA Office of Advocacy, September 2012. [Online] Available: http://www.sba.gov/sites /default/files/files/Finance\%20FAQ\%208-25-11\%20FINAL\%20for\%20web.pdf (May 15, 2014).

Small Business Authority of Israel - SBAI (2011). Report on Government Strategy to Support SMEs. [Online] Available: http://sba.tamat.gov.il/About/Pages/strategic.aspx (May 15, 2014).

Small Business Authority of Israel - SBAI (2013). About Us. [Online] Available: http://sba.tamat.gov.il/About/Pages/default.aspx (May 15, 2014).

Ulvenblad, P., Berggren, E., \& Winborg, J. (2013). The role of entrepreneurship education and start-up experience for handling communication and liability of newness. International Journal of Entrepreneurial Behaviour \& Research, 19(2), 187-209. http://dx.doi.org/10.1108/13552551311310374

United Nations Development Programme - UNDP (2013). Human Development Report 2013, Israel. [Online] Available: http://hdrstats.undp.org/images/explanations/ISR.pdf (May 15, 2014).

Van Auken, H., Kaufmann, J., \& Herrmann, P. (2009). An empirical analysis of the relationship between capital acquisition and bankruptcy laws. Journal of Small Business Management, 47(1), 23-37. http://dx.doi.org/10.1111/j.1540-627X.2008.00260.x

Van Gelder, J. L., De Vries, R. E., Frese, M., \& Goutbeek, J. P. (2007). Differences in Psychological Strategies of Failed and Operational Business Owners in the Fiji Islands*. Journal of Small Business Management, 45(3), 388-400. http://dx.doi.org/10.1111/j.1540-627X.2007.00219.x

Wainer, D (2013). The Upside to Traffic Snarls in Tel Aviv. BusinessWeek (Electronic Version) (June 20), 40.

Westhead, P., Wright, M., \& Ucbasaran, D. (2001). The internationalization of new and small firms: A resource-based view. Journal of business venturing, 16(4), 333-358. http://dx.doi.org/10.1016/S0883-9026(99)00063-4

World Bank (2011). Research and development expenditure (\% of GDP). [Online] Available: http://data.worldbank.org/indicator/GB.XPD.RSDV.GD.ZS/countries/1W-IL? display=default (May 15, 2014).

World Economic Forum - WEF (2013). The Global Competitiveness Report 2011-2012. [Online] Available: http://www3.weforum.org/docs/WEF_GCR_Report_2011-12.pdf (May 15, 2014). 


\section{Copyright Disclaimer}

Copyright for this article is retained by the author(s), with first publication rights granted to the journal.

This is an open-access article distributed under the terms and conditions of the Creative Commons Attribution license (http://creativecommons.org/licenses/by/3.0/). 